\title{
Sea turtles and survivability in demersal trawl fisheries: Do comatose olive ridley sea turtles survive post-release?
}

\author{
Sara M. Maxwell ${ }^{1} 10^{*} \mathbb{C}$, Matthew J. Witt ${ }^{2}$, Gaspard Abitsi ${ }^{3}$, Marie Pierre Aboro ${ }^{4}$, Pierre Didier Agamboue ${ }^{3}$, \\ Georges Mba Asseko ${ }^{5}$, François Boussamba ${ }^{4}$, Emmanuel Chartrain ${ }^{4}$, Micheline Schummer Gnandji6 \\ Brice Didier Koumba Mabert ${ }^{7}$, Felicien Mavoungou Makanga ${ }^{4}$, Jean Churley Manfoumbi ${ }^{8}$, \\ Jean Noel Bibang Bi Nguema ${ }^{5}$, Jacob Nzegoue ${ }^{3}$, Carmen Karen Kouerey Oliwina ${ }^{3}$, Guy-Philippe Sounguet ${ }^{4,9}$ \\ and Angela Formia ${ }^{3}$
}

\begin{abstract}
Incidental capture of air-breathing species in fishing gear is a major source of mortality for many threatened populations. Even when individuals are discarded alive, they may not survive due to direct injury, or due to more cryptic internal physiological injury such as decompression sickness. Post-release mortality, however, can be difficult to determine. In this pilot study, we deployed survivorship pop-up archival tags (sPAT) $(n=3)$ for an air-breathing species, the olive ridley sea turtle (Lepidochelys olivacea), one of the first studies to do so. We found that at least two of the three turtles survived after being captured in demersal fish trawl nets and being resuscitated from a comatose state following standard UN Food and Agriculture Organization guidelines. One turtle died; however, the absence of a change in light level but continued diving activity suggested that the turtle was likely predated. Whether capture contributed to the turtle's susceptibility to predation post-release is unknown, and average tow duration during this fishing trip was similar in duration to that of a turtle that survived $(1.5 \mathrm{~h}$ ). The two surviving turtles displayed normal horizontal and vertical movements based on previous tagging studies. This study suggests that resuscitation techniques may be effective; however, additional study is necessary to increase sample sizes, and to determine the severity of decompression sickness across different levels of activity and in other fishing gears. This will result in better population mortality estimates, as well as highlight techniques to increase post-release survivorship.
\end{abstract}

Keywords: Post-release mortality, Trawl fishing, Bycatch, Resuscitation, Decompression sickness, Olive ridley sea turtle

\section{Background}

Fisheries bycatch, or the incidental capture of non-target species in fishing gear, is a major human threat to marine species worldwide [1]. Air-breathing species may drown in nets or on lines used for fishing [2]. Generally, individuals captured as bycatch are not marketable species, either due to limited human demand or due to regulatory restrictions, and are discarded either dead or alive, or

\footnotetext{
*Correspondence: smmax@uw.edu

${ }^{1}$ Department of Biological Sciences, Old Dominion University, Norfolk, VA, USA

Full list of author information is available at the end of the article
}

may be used as bait [1]. Sea turtles are a large marine species caught as bycatch, and the recovery of their populations worldwide has been impeded by bycatch in marine fisheries, particularly fishing trawls [3]. Trawls operate by towing a large funnel-shaped net across the sea bottom or through the water column to capture target species; however, trawls indiscriminately capture other species as well, including sea turtles that co-occur with target species such as shrimp and fish. Gear modifications such as turtle excluder devices (TEDs) have been introduced to reduce the capture of sea turtles in trawl nets. The use of TEDs has resulted in increase in some sea turtle 
populations [4]; however, TEDs are not required in many parts of the world, or across all fisheries that may come into contact with sea turtles [5].

Capture of sea turtles in trawls (and other gear types) can result in traumatic injury and in physiological impacts due to forced submergence (reviewed in [6]). While sea turtles have behavioral and physiological adaptations to reduce the potential of decompression sickness in their normal diving activity $[7,8]$, there is evidence that capture in fishing operations results in increased metabolic and locomotor activity, and exertional myopathy [9]. As a result, turtles experience physiological changes that likely override adaptations for reducing decompression sickness, resulting in deleterious effects [10]. In addition to death due to drowning, lactate levels may increase, stress-related hormones may increase, and turtles' ability to recover may be further impacted by increases in other blood chemistry values such as glucose, phosphorus, potassium and creatine phosphokinase that indicate metabolic disturbance $[6,8,11-14]$. As a result of these physiological impacts, many turtles are also brought onboard fishing vessels in a comatose state, where they are unresponsive but still alive. They can potentially be resuscitated from this state, and several protocols exist for resuscitation (e.g., $[5,15,16]$ ), of which one of the most common is elevation of the rear end of the turtle to allow the lungs to drain. Resuscitation may occur for up to $24 \mathrm{~h}$, or until the turtle appears vagile and alert (reanimated) at which point it is released from the vessel.

Despite resuscitation, survivorship of sea turtles postrelease is largely unknown, as physiological impacts may affect long-term survivorship, with decompression sickness of particular concern. Decompression sickness results from forced submergence and rapid ascension to the surface as nets are retrieved to the vessel $[10,17]$. Decompression sickness occurs from rapid degassing of nitrogen from solutes, resulting in nitrogen gas bubble formation in the blood stream and tissues causing severe pathological impacts. This may result in death, though death may occur after a turtle has been released alive from a fishing vessel, making it difficult to know the true survivorship of turtles. When mortality occurs post-release, it can be difficult to account for this 'cryptic' source of mortality in population estimates and management efforts [18]. While telemetry devices have been used in the past to infer survivorship of sea turtles and other marine species [19-23], it has traditionally been difficult to definitively distinguish the failure of devices from death of a tagged animal $[24,25]$.

Recently, technology has been developed that allows for the determination of survivorship of marine species once they are released. Survivorship pop-up archival (sPAT) tags developed by Wildlife Computers Inc.
(Redmond WA USA) are released from a tagged individual after 30 days unless putative death is detected prior to the programmed release date. A combination of light and depth levels is used to infer the animal death as a result of either: (a) floating continuously on the surface (floater) or (b) sank to the bottom (sinker). Tags that detach at 30 days post-release and where neither 'floater' nor 'sinker' states have been activated are considered survivors for the purposes of this study. Potential predation and subsequent ingestion of an animal can also be inferred by a lack of change in light levels, indicating that dawn and dusk were not detectable.

SPAT tags have been used to determine post-bycatch survivorship in several elasmobranchs including mako sharks (Isurus oxyrinchus, [26]), silky sharks (Carcharhinus falciformis, [27]), school sharks (Galeorhinus galeus, [28]), great hammerheads (Sphyrna mokarran, [29]) and spinetail devil rays (Mobula japonica, [30]) but application to air-breathing marine species subject to decompression sickness, such as sea turtles has been limited, though satellite tags have been used to infer survivorship but using more limited data (e.g., [19, 24]). Here, we deployed sPAT tags to determine survivorship of olive ridley sea turtles (Lepidochelys olivacea) captured in demersal fish trawling vessels in Gabon, Africa. Gabon regularly hosts four sea turtle species, including leatherback (Dermochelys coriacea), green (Chelonia mydas), hawksbill (Eretmochelys imbricata) and olive ridley sea turtles [31-35]. Many of these species are caught in trawling nets; however, olive ridleys are caught in disproportionately large numbers compared to the number of individuals in the local population [36], making trawling of particular concern. We illustrate attachment design and procedure, and results of the deployment of three sPAT tags in pilot study conducted in 2016. We discuss

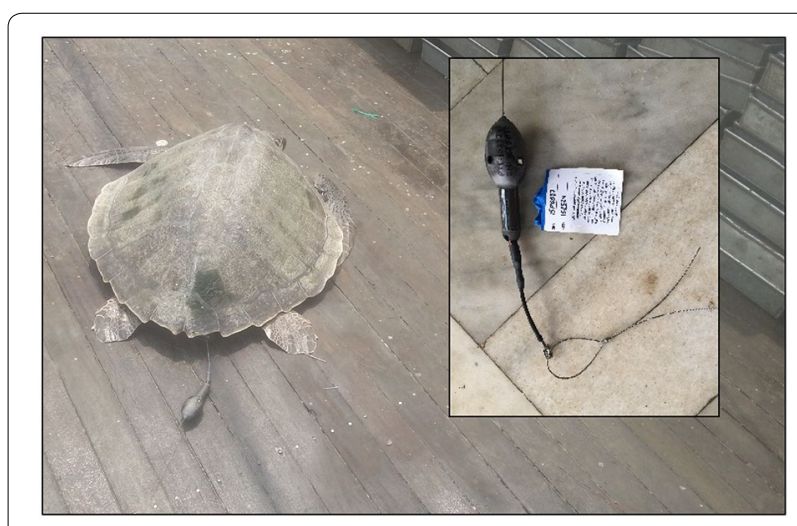

Fig. 1 Olive ridley turtle on deck of fishing vessel fitted with Wildlife Computers survivorship pop-up archival tag attached using a short tether to attach to the rear supracaudal scutes. Inset: survivorship tag 


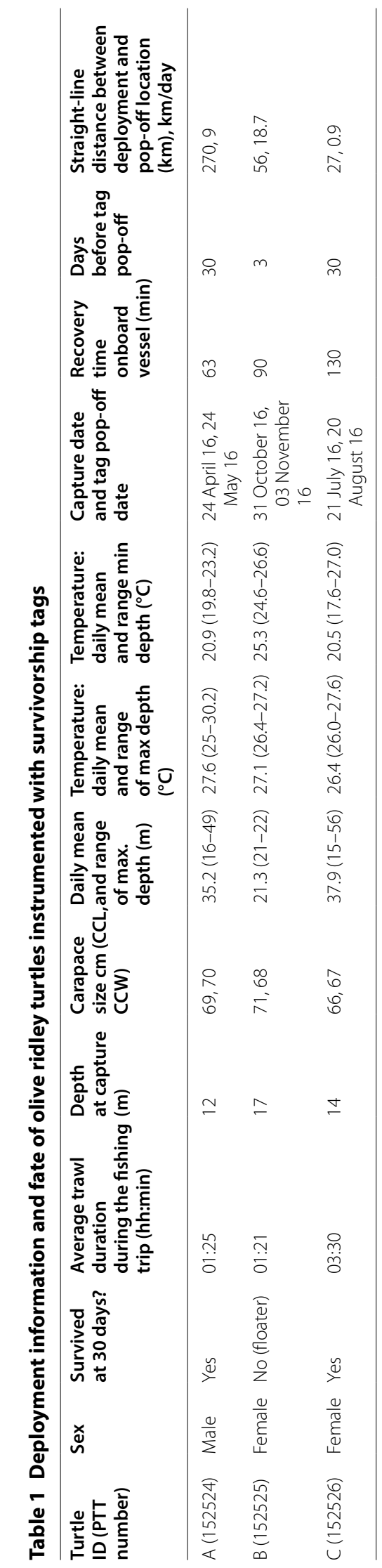


the potential implications of these results on the larger population, and implications for management.

\section{Methods}

Survivorship pop-up archival (sPAT) tags (Wildlife Computers, Redmond WA, USA; $124 \mathrm{~mm}$ length $\times 38 \mathrm{~mm}$ maximum height, approximately $60 \mathrm{~g}$ in air) were deployed on three olive ridley sea turtles captured in the commercial demersal fish trawl fishery in coastal Gabon, Africa (Fig. 1). Turtle excluder devices (TEDs) are required on shrimp trawling vessels in Gabon but not on demersal fish trawling vessels, which represent over $80 \%$ of the trawling fleet [36]. Two adult females and one adult male were instrumented with transmitters in April, July and October of 2016 (Table 1). Tags were attached opportunistically by trained fishery observers to turtles brought aboard in a comatose state (alive but unresponsive). Turtles were captured in demersal trawl gear, brought onboard the fishing vessel and resuscitated by elevating the rear end of the turtle. The tag was attached once the turtle was reanimated. Curved carapace length (CCL) was measured, and Inconel flipper tags (National Band and Tag Company, USA) attached to the front left and right flippers prior to release from the vessel. Release location and time were recorded, as was water depth at the capture location. Additionally, the average duration of trawls within each approximately 3-day fishing trip was recorded, however, the duration of individual trawls was not available.

\section{Tag attachment and operation}

Tags were attached to the turtle at the left or right supracaudal scute of the carapace (Fig. 1). A power drill was used to drill a small (approximately $3 \mathrm{~cm}$ diameter) hole in the scute, and tags were attached using a metal wire and crimps. Once deployed, tags were automatically activated by exposure to saltwater. Tags operated for up to 30 days. If a turtle died, the tag was released from the turtle via a corrodible pin. If a turtle was considered dead, it was classified into one of two groups based on the time-depth recorder within the tag: floated continuously on the surface for $24 \mathrm{~h}$ (floater), or sank to the bottom and remained at a consistent depth for $24 \mathrm{~h}$ (sinker). Additionally, the tag is designed to detect if there is a change in light level over a $24-\mathrm{h}$ period in order to indicate potential predation events; if dawn or dusk were not detected, but change in depth occurs, this indicated the tag had likely been ingested. If mortality was not observed after 30 days, the tag was released via a corrosive pin and the turtle considered alive. The tag further reports if the corrodible pin has been broken or corroded when released within the 30 -day period. The release location and survivorship status of the turtle, as well as daily minimum and maximum depth, daily minimum and maximum water temperature, and if there was a light level change over the $24-\mathrm{h}$ period prior to release, were transmitted via the Argos satellite system once the tag was released.

\section{Results}

Of the three turtles instrumented, two of the turtles survived (Turtles A and C), while one is presumed dead (Turtle B) and was categorized as a 'floater' (Table 1). Data transmitted by the tag suggest that this turtle may have been predated as no change in the light level for $24 \mathrm{~h}$ was detected prior to tag release, but the tag was not recorded at the surface during that 24-h period (Fig. 2). Additionally, in the $24 \mathrm{~h}$ prior, the turtle was diving, though it is possible that the turtle died and was then consumed, or that the tag was consumed and not the turtle.

Average tow duration during the fishing trips during which Turtle A and B were caught were approximately $1.3 \mathrm{~h}$; however, average tow durations for Turtle C's trip were considerably longer, averaging $3.5 \mathrm{~h}$ (Table 1 ). Turtles were caught in depths ranging from 12 to $17 \mathrm{~m}$, with the presumed dead turtle (Turtle B) caught at the greatest depth $(17 \mathrm{~m}$; Table 1$)$. Turtle movements varied considerably (Fig. 3). The greatest straight-line distance was $270 \mathrm{~km}$ south in 30 days (Turtle A; Table 1), but distance per day was as low as $0.9 \mathrm{~km} / \mathrm{d}$ for Turtle $C$ which appeared to remain in the vicinity where capture occurred near the mouth of the Komo Estuary. The Komo Estuary is adjacent to a known nesting site, and some olive ridley turtles nesting there are known to remain resident in the area for the months following nesting [37]. The nesting season occurs from September through March with a peak in November [32], and this turtle was recorded in the area in the area in July and August, further suggesting this may be a resident foraging ground during other parts of the year.

Turtles experienced mean minimum daily temperatures between 20.5 and $25.3{ }^{\circ} \mathrm{C}$, with maximum mean daily temperatures of $27.6{ }^{\circ} \mathrm{C}$ (Fig. 2, Table 1). Maximum daily dive depths ranged from 21.3 to $37.9 \mathrm{~m}$, though the tag attached to turtle B reported the shallowest depth (21.3) and collected only 3 days of data before presumed death and tag release (Fig. 2). The maximum dive depth recorded by any of the turtles was $56 \mathrm{~m}$.

\section{Discussion}

Our results, while preliminary, suggest post-release mortality occurred in a single individual following resuscitation from a comatose state. Two of the three turtles 

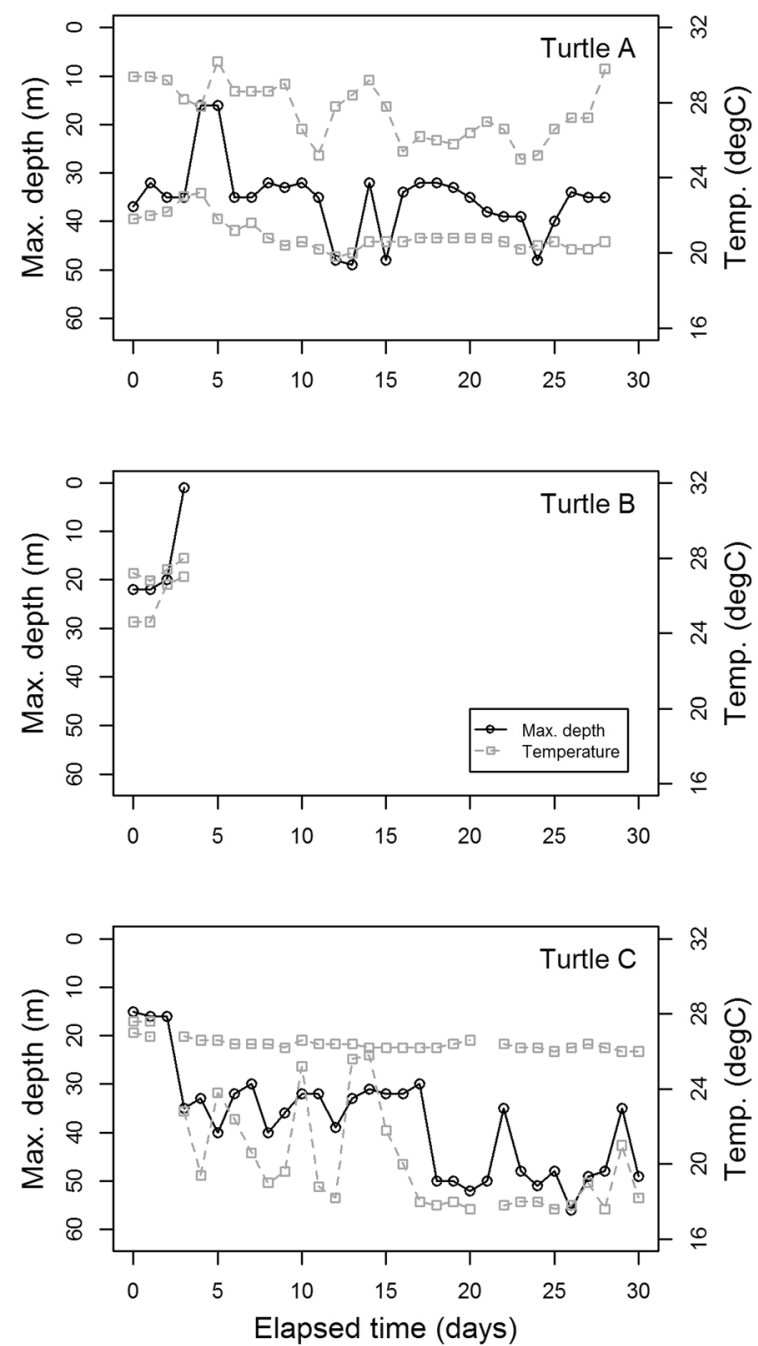

Fig. 2 Daily maximum depth (black) and minimum and maximum temperatures (gray) of three olive ridley turtles instrumented with Wildlife Computers survivorship pop-up archival tags (sPAT). Turtles $A$ and $C$ survived, and tags were programed to release after 30 days. Turtle B was characterized as a 'floater' as its maximum depth on the fourth day was $1 \mathrm{~m}$; however, it was likely predated, as there was no change in light level on the third day, as indicated by the star

survived, and while a third died, it appears to be due to predation; however, it is unknown whether injuries or changes in behavior from trawl capture could have made it more susceptible to predation, or if it died and was then scavenged shortly thereafter. Depth of capture was greatest for the turtle that died (Turtle B $17 \mathrm{~m}$; Table 1). Mean tow duration, however, for the turtle that died (Turtle B, 1:21) was similar (Turtle A, 1:25) or half as long (Turtle $\mathrm{C}, 3: 30$ ) as the turtles that lived, complicating speculation as to whether capture may have played a part in its death (though it should be noted that the exact tow duration for these capture events are unknown). No direct injuries to the turtle were observed, but it is possible that other physiological impacts such as aspirational pneumonia, exertional myopathy or decompression sickness may have occurred despite a relatively short tow time, resulting in increased susceptibility to predators. These results highlight the need for further research beyond this pilot study.

Implementation of onboard resuscitation is likely a useful post-capture management technique in this fishery, and mandating these techniques along with additional outreach to fishers, is worthwhile. The mean maximum dive depths for these instrumented turtles (Fig. 2) are similar to dive depths recorded for turtles in other parts of the world (Australia, [38, 39]; French Guiana, [40]), as well as from previous studies in this region on nesting female turtles [37], suggesting potentially 'normal' dive behavior of turtles post-release, though we caution that the tags did not collect the full dive profile data to allow us to fully assess behavior, and that Turtle B's tag collected only 3 days of data before death and subsequent release. We additionally caution that there may be a greater risk for decompression sickness when capture occurs at greater depths, or in other regions of the world where water temperatures are colder. Gabon resides on the equator and the turtles in this study encountered mean water temperatures between 20.5 and $27.6{ }^{\circ} \mathrm{C}$ (range $17.6-30.2{ }^{\circ} \mathrm{C}$; Table 1). Solubility of nitrogen at depth increases proportionally with decreasing temperatures, so it is critical to conduct similar survivorship studies in more temperate regions where turtles are subject to bycatch, as well as on species that are likely to dive to greater depths or in fisheries where trawling occurs at greater depths.

Applying these preliminary results to the demersal fish trawl fishery in Gabon [36], survival following very basic resuscitation of trawl-captured sea turtles may be higher than expected, which would reduce the predicted mortality of ridleys in this trawl fishery by a proportion yet to be determined. We urge very strong caution in interpreting these results, however, given three factors. First, our sample size is low and second, captures occurred in relatively shallow, nearshore waters (between 12 and $17 \mathrm{~m}$ depth). Casale et al. [36] indicate that the fishery also occurs further offshore in relatively high density and in some cases nearing $200 \mathrm{~m}$ depths (see Figure 1 in [36]). These depths are likely to greatly influence ridleys susceptibility to decompression sickness and other associated physiological impacts as olive ridleys appear to spend considerable time on the seafloor bottom where they are caught in this fishery [37]. Third, mortality in this fishery may occur for non-comatose turtles released alive. Individuals that are hyperactive when brought onboard often 


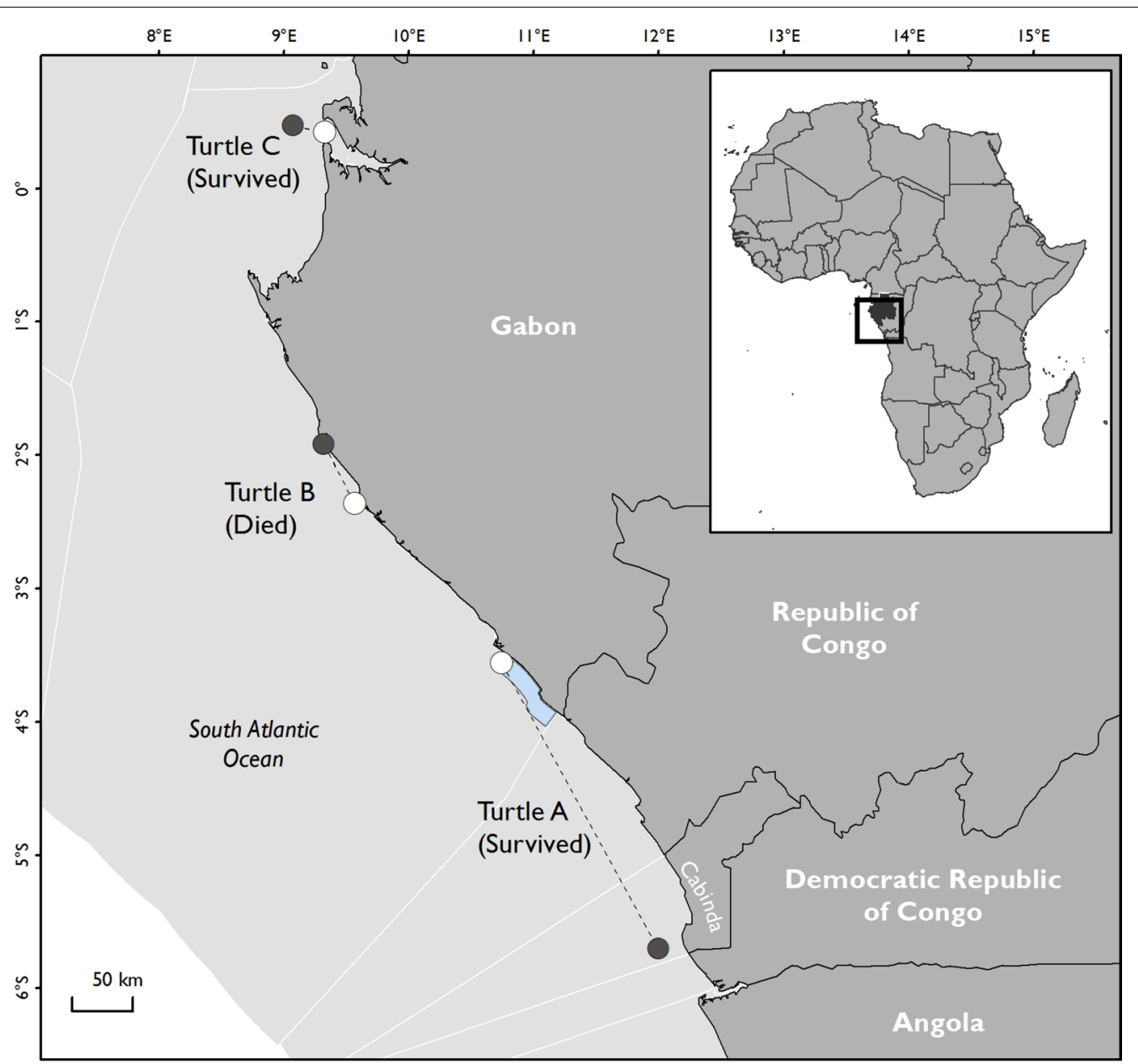

Fig. 3 Deployment (white circles) and pop-up (black circles) locations of three olive ridley turtles instrumented with Wildlife Computers survivorship pop-up archival tags (SPAT) and survivorship status of turtles A-C indicated (died or survived). Inferential movement between deployment and pop-up locations (black broken line). Inset map: African continent and Gabon (black filled polygon) with geographic extent of study region (black polygon)

subsequently develop decompression sickness [10, 17]. As a result, these turtles may subsequently die as they are likely to be released almost immediately after landing, as they are alive and animated. Our post-release survivorship estimates were biased toward turtles that were comatose upon landing, and turtles with a strong locomotor response would likely have been recorded as 'alive.' Post-release survival of hyperanimated turtles is another important area of study.

Understanding post-release mortality is critical, and studies have looked at post-release mortality across other gear types and fisheries. For example, turtles lightly hooked in longline fisheries show no difference between control turtles in diving behavior [22] or mortality [21, 22]. In coastal gillnets, post-release mortality was higher than in longlines $(28.6 \%$ [41]). While we focus here on trawl gear, other gear types are used in the Central West
African region that may impact turtles, including purse seines, longlines and gillnets. Artisanal gillnets are widespread in Gabon and other areas of Central West Africa, particularly in coastal and estuarine habitats where turtles are found, and these fisheries use long soak times $(12+\mathrm{h})[42,43]$. While depth does impact severity of decompression sickness, Fahlman et al. [17] provided evidence that the time of submergence is also critically important, as moderate and severe decompression sickness was observed more often when turtles were submerged for longer, such as in gillnets, even when set at moderate depths of only $10-20 \mathrm{~m}$. This indicates a critical need to also conduct similar survivorship studies in gillnet fisheries where turtles are frequently caught in artisanal fishing operations [43], and to better understand how the combination depth and time of submergence may influence survivorship. 
While this study suggests that post-release mortality may be moderate, Casale et al. [36] indicates that $6.2 \%$ of turtles are brought aboard fish trawling vessels already dead. In Gabon, TEDs are required for shrimp trawling vessels but not demersal fish trawl vessels. The majority of trawlers in Gabon target fish $(87.5 \%, n=28)$, and shrimp trawlers amount to only $12.5 \%$ of the Gabonese trawl fleet $(n=4)$, and largely operate in the bay of PortGentil, an isolated area approximately $250 \mathrm{~km}^{2}$. There is clearly a need for TEDs in demersal fish trawling operations; however, TEDs operate by excluding large items from entering the cod end while retaining small items such as shrimp. In demersal fish trawling operations, large-bodied fish are targeted, so design needs to allow fishermen to maintain levels of target catch. Gabon is currently developing a design for TEDs adapted to its fish trawling fleet that will minimize sea turtle bycatch, and it is hoped it will soon be written into law.

\section{Authors' contributions}

SMM, MJW and AF conceived the study and conducted data analyses. All authors contributed to the data collection, logistics and the manuscript. All authors read and approved the final manuscript.

\section{Author details \\ ${ }^{1}$ Department of Biological Sciences, Old Dominion University, Norfolk, VA, USA \\ ${ }^{2}$ College of Life and Environmental Sciences, University of Exeter, Exeter, UK. \\ ${ }^{3}$ Marine Program, Wildlife Conservation Society, BP 7847, Libreville, Gabon. ${ }^{4}$ Pro- gramme Observateurs Gabon, Aventures Sans Frontieres, BP 7248, Libreville, Gabon. ${ }^{5}$ Agence Nationale des Peches et de l'Aquaculture, BP 20484, Libreville, Gabon. ${ }^{6}$ Direction Generale des Peches et de I'Aquaculture, BP 9498, Libreville, Gabon. ${ }^{7}$ Centre National des Donnees et de l'Information Oceanographiques, BP 10961, Libreville, Gabon. ${ }^{8}$ Ibonga-ACPE, BP 178, Gamba, Gabon. ${ }^{9}$ Agence Nationale des Parcs Nationaux, BP 20379, Libreville, Gabon. ${ }^{10}$ Present Address: School of Interdisciplinary Arts and Sciences, University of Washington, Bothell Campus, 18115 Campus Way NE, Bothell, WA 98011, USA.}

\section{Acknowledgements}

We acknowledge the support and authorizations for this research and for Gabon's onboard observer program by the Agence Nationale des Peches et de l'Aquaculture, the Direction Generale des Pêches et de l'Aquaculture, the Agence Nationale des Parcs Nationaux and the Centre National de la Recherche Scientifique et Technologique.

\section{Competing interests}

The authors declare that they have no competing interests.

\section{Availability of data and materials}

The datasets used and/or analyzed during the current study are available from the corresponding author on reasonable request, though the majority of data generated or analyzed during this study are included in this published article.

\section{Consent for publication}

Not applicable.

\section{Ethics approval and consent to participate}

All federal, international, and institutional guidelines were followed, and this study was approved by and carried out in accordance with the recommendations of the Institutional Animal Care and Use Committee at Old Dominion University (IACUC Permit 15-016). Permissions to work with the study species were issued by the Gabon Agence Nationale des Parcs Nationaux (AEI5025, AR0010/12, AE140003). Gabon's onboard observer program is carried out with permissions from the Agence Nationale des Peches et de l'Aquaculture, the Direction Generale des Pêches et de l'Aquaculture, and the Centre National de la Recherche Scientifique et Technologique.

\section{Funding}

Funding for tags and equipment was provided by Old Dominion University. The Gabon Sea Turtle Partnership, which funded observer logistics, is funded by the Marine Turtle Conservation Fund (US Fish and Wildlife Service, Department of the Interior)

\section{Publisher's Note}

Springer Nature remains neutral with regard to jurisdictional claims in published maps and institutional affiliations.

Received: 12 March 2018 Accepted: 20 August 2018

Published online: 10 September 2018

\section{References}

1. Hall MA, Alverson DL, Metuzals KI. By-catch: problems and solutions. Mar Pollut Bull. 2000:41:204-19.

2. Lewison RL, Crowder LB, Wallace BP, Moore JE, Cox T, Zydelis R, McDonald S, DiMatteo A, Dunn DC, Kot CY, et al. Global patterns of marine mammal, seabird, and sea turtle bycatch reveal taxa-specific and cumulative megafauna hotspots. Proc Natl Acad Sci USA. 2014;111:5271-6.

3. Crouse DT, Crowder LB, Caswell H. A stage-based population-model for loggerhead sea-turtles and implications for conservation. Ecology. 1987;68:1412-23.

4. Crowder LB, Crouse DT, Heppell SS, Martin T. Predicting the impact of turtle excluder devices on loggerhead sea turtle populations. Ecol Appl. 1994:4:437-45.

5. FAO Fisheries and Aquaculture Department: Guidelines to reduce sea turtle mortality in fishing operations. Rome: FAO; 2009:141, p. 141.

6. Wilson SM, Raby GD, Burnett NJ, Hinch SG, Cooke SJ. Looking beyond the mortality of bycatch: sublethal effects of incidental capture on marine animals. Biol Conserv. 2014;171:61-72.

7. Lutcavage ME, Lutz PL. Diving physiology. Biol Sea Turt. 1997;1:277-96.

8. Hooker SK, Fahlman A, Moore MJ, De Soto NA, De Quiros YB, Brubakk AO, Costa DP, Costidis AM, Dennison S, Falke K. Deadly diving? Physiological and behavioural management of decompression stress in diving mammals. Proc R Soc B. 2012;279:1041-50.

9. Phillips BE, Cannizzo SA, Godfrey MH, Stacy BA, Harms CA. Exertional myopathy in a juvenile green sea turtle (Chelonia mydas) entangled in a large mesh gillnet. Case Rep. Vet Med. 2015;2015:604320.

10. Garcia-Parraga D, Crespo-Picazo J, Bernaldo de Quiros Y, Cervera V, MartíBonmati L, Díaz-Delgado J, Arbelo M, Moore MJ, Jepson PD, Fernández A. Decompression sickness ('the bends') in sea turtles. Dis Aquat Org. 2014;111:191-205.

11. Williard A, Parga M, Sagarminaga R, Swimmer Y. Physiological ramifications for loggerhead turtles captured in pelagic longlines. Biol Lett. 2015;11:20150607.

12. Snoddy JE, Landon M, Blanvillain G, Southwood A. Blood biochemistry of sea turtles captured in gillnets in the lower Cape Fear River, North Carolina, USA. JWildl Manag. 2009;73:1394-401.

13. Innis CJ, Merigo C, Cavin JM, Hunt K, Dodge KL, Lutcavage M. Serial assessment of the physiological status of leatherback turtles (Dermochelys coriacea) during direct capture events in the northwestern Atlantic Ocean: comparison of post-capture and pre-release data. Conserv Physiol. 2014. https://doi.org/10.1093/conphys/cou048

14. Hoopes LA, Landry AM Jr, Stabenau EK. Physiological effects of capturing Kemp's ridley sea turtles, Lepidochelys kempii, in entanglement nets. Can J Zool. 2000;78:1941-7.

15. Eayrs S. A guide to bycatch reduction in tropical shrimp-trawl fisheries. revised ed. Rome: FAO; 2007. p. 108.

16. Federal Register. Sea turtle conservation; restrictions applicable to fishing and scientific research activities. In: Service NMF editor, vol. 66. Washington; 2001. p. 67495-67496.

17. Fahlman A, Crespo-Picazo JL, Sterba-Boatwright B, Stacy BA, Garcia-Parraga $D$. Defining risk variables causing gas embolism in loggerhead sea turtles (Caretta caretta) caught in trawls and gillnets. Sci Rep. 2017;7:2739.

18. Gilman E, Suuronen P, Hall M, Kennelly S. Causes and methods to estimate cryptic sources of fishing mortality. J Fish Biol. 2013;83:766-803. 
19. Swimmer Y, Empey Campora C, McNaughton L, Musyl M, Parga M. Postrelease mortality estimates of loggerhead sea turtles (Caretta caretta) caught in pelagic longline fisheries based on satellite data and hooking location. Aquat Conserv Mar Freshw Ecosyst. 2014;24:498-510.

20. Skomal G. Evaluating the physiological and physical consequences of capture on post-release survivorship in large pelagic fishes. Fish Manag Ecol. 2007;14:81-9.

21. Sasso CR, Epperly SP. Survival of pelagic juvenile loggerhead turtles in the open ocean. J Wildl Manag. 2007;71:1830-5.

22. Swimmer Y, Arauz R, McCracken M, McNaughton L, Ballestero J, Musyl M, Bigelow K, Brill R. Diving behavior and delayed mortality of olive ridley sea turtles Lepidochelys olivacea after their release from longline fishing gear. Mar Ecol Prog Ser. 2006;323:253-61.

23. Mangel JC, Alfaro-Shigueto J, Witt MJ, Dutton PH, Seminoff JA, Godley BJ. Post-capture movements of loggerhead turtles in the southeastern Pacific Ocean assessed by satellite tracking. Mar Ecol Prog Ser. 2011;433:261-72.

24. Hays GC, Broderick AC, Godley BJ, Luschi P, Nichois WJ. Satellite telemetry suggests high levels of fishing-induced mortality in marine turtles. Mar Ecol Prog Ser. 2003;262:305-9.

25. Hays GC, Forman DW, Harrington LA, Harrington AL, MacDonald DW, Righton D. Recording the free-living behaviour of small-bodied, shallowdiving animals with data loggers. J Anim Ecol. 2007;76:183-90.

26. French RP, Lyle J, Tracey S, Currie S, Semmens JM. High survivorship after catch-and-release fishing suggests physiological resilience in the endothermic shortfin mako shark (Isurus oxyrinchus). Conserv Physiol. 2015:3:cov044.

27. Hutchinson MR, Itano DG, Muir JA, Holland KN. Post-release survival of juvenile silky sharks captured in a tropical tuna purse seine fishery. Mar Ecol Prog Ser. 2015;521:143-54.

28. Rogers P, Knuckey I, Hudson R, Lowther A, Guida L. Post-release survival, movement, and habitat use of school shark Galeorhinus galeus in the Great Australian Bight, southern Australia. Fish Res. 2017;187:188-98.

29. Drymon JM, Wells RD. Double tagging clarifies post-release fate of great hammerheads (Sphyrna mokarran). Anim Biotelem. 2017;5:28.

30. Francis MP, Jones EG. Movement, depth distribution and survival of spinetail devilrays (Mobula japanica) tagged and released from purseseine catches in New Zealand. Aquat Conserv Mar Freshw Ecosyst. 2017;27:219-36.

31. Witt MJ, Baert B, Broderick AC, Formia A, Fretey J, Gibudi A, Mounguengui GAM, Moussounda C, Ngouessono S, Parnell RJ, et al. Aerial surveying of the world's largest leatherback turtle rookery: a more effective methodology for large-scale monitoring. Biol Conserv. 2009;142:1719-27.
32. Metcalfe K, Agamboué PD, Augowet E, Boussamba F, Cardiec F, Fay JM, Formia A, Kema JRK, Kouerey C, Mabert BDK. Going the extra mile: ground-based monitoring of olive ridley turtles reveals Gabon hosts the largest rookery in the Atlantic. Biol Conserv. 2015;190:14-22.

33. Formia A, Tiwari M, Fretey J, Billes A. Sea turtle conservation along the Atlantic coast of Africa. Mar Turt Newsl. 2003;100:33-7.

34. Fretey J. Biogeography and conservation of marine turtles of the Atlantic Coast of Africa. In UNEP/CMS Secretariat 6. Bonn, Germany; 2001.

35. Maxwell SM, Breed GA, Nickel BA, Makanga-Bahouna J, Pemo-Makaya E, Parnell RJ, Formia A, Ngouessono S, Godley BJ, Costa DP, et al. Using satellite tracking to optimize protection of long-lived marine species: olive ridley sea turtle conservation in Central Africa. PLoS ONE. 2011;6:e19905.

36. Casale P, Abitsi G, Aboro MP, Agamboue PD, Agbode L, Allela NL, Angueko D, Nguema JNBB, Boussamba F, Cardiec F. A first estimate of sea turtle bycatch in the industrial trawling fishery of Gabon. Biodivers Conserv 2017;26(10):2421-33.

37. Dawson TM, Formia A, Agamboué PD, Asseko GM, Boussamba F, Cardiec F, Chartrain E, Doherty PD, Fay JM, Godley BJ. Informing marine protected area designation and management for nesting olive ridley sea turtles using satellite tracking. Front Mar Sci. 2017:4:312.

38. McMahon CR, Bradshaw CJA, Hays GC. Satellite tracking reveals unusual diving characteristics for a marine reptile, the olive ridley turtle Lepidochelys olivacea. Mar Ecol Prog Ser. 2007;329:239-52.

39. Whiting S, Long J, Coyne M. Migration routes and foraging behaviour of olive ridley turtles Lepidochelys olivacea in northern Australia. Endanger Species Res. 2007;3:1-9.

40. Plot V, De Thoisy B, Georges J-Y. Dispersal and dive patterns during the post-nesting migration of olive ridley turtles from French Guiana. Endanger Species Res. 2015;26:221-34.

41. Snoddy JE, Williard AS. Movements and post-release mortality of juvenile sea turtles released from gillnets in the lower Cape Fear River, North Carolina, USA. Endanger Species Res. 2010;12:235-47.

42. Parnell R, Verhage B, Deem SJ, Van Leeuwe T, Nishihara T, Moukoula C, Gibudi A. Marine turtle mortality in Southern Gabon and Northern Congo. Mar Turt Newsl. 2007;116:12-4.

43. Riskas KA, Tiwari M. An overview of fisheries and sea turtle bycatch along the Atlantic coast of Africa. In: Zaldua-Mendizabal N, Egaña-Callejo A, editors. Marine turtles of the North East Atlantic contributions for the first regional conference Munibe monographs nature series 1. San Sebastian: Aranzadi Society of Sciences; 2012. p. 71-82.
Ready to submit your research? Choose BMC and benefit from:

- fast, convenient online submission

- thorough peer review by experienced researchers in your field

- rapid publication on acceptance

- support for research data, including large and complex data types

- gold Open Access which fosters wider collaboration and increased citations

- maximum visibility for your research: over $100 \mathrm{M}$ website views per year

At BMC, research is always in progress.

Learn more biomedcentral.com/submissions 